\title{
The Literary Works of François Fénelon on the Achievement of Child Well-being
}

\author{
Aikaterini X. Ioannou ${ }^{1 \star}$, Konstantinos D. Malafantis ${ }^{2^{\star \star}}$
}

\author{
${ }^{1}$ Philologist, MSc in Applied Pedagogy, National and Kapodistrian University of Athens, Faculty of Primary Education, School of Education, GREECE \\ ${ }^{2}$ Professor of Education and Literature, President of the Hellenic Educational Society, Faculty of Primary Education, School of Education, National and Kapodistrian \\ University of Athens, GREECE \\ *Corresponding Author: aikatioan@primedu.uoa.gr \\ ${ }^{\star \star}$ Corresponding Author: kmalafant@primedu.uoa.gr
}

Citation: Ioannou, A. X., \& Malafantis, K. D. (2020). The Literary Works of François Fénelon on the Achievement of Child Well-being. Pedagogical Research, 5(2), em0061. https://doi.org/10.29333/pr/7939

\section{ARTICLE INFO}

Received: 16 Mar. 2020

Accepted: 19 Mar. 2020

\begin{abstract}
The French Archbishop of Cambrai and pedagogue François Fénelon (1651-1715), was the tutor of the grandson of Louis XIV. Based on his classical education, he wrote the pedagogical books Education of Girls and The Adventures of Telemachus, The Son of Ulysses. This paper seeks to examine, according to the historical method of analysis, how the moral value and didactic spirit of these literary pieces influenced the European philosophical and pedagogical thinking, they contributed to the cultivation of moral values among young people and they are classical references for the achievement of children's well-being.

Being both priest and pedagogue, Fénelon considered that education is key to welfare and he encouraged the cultivation of moral virtue. His contribution to the philosophy of education is worthwhile, since, in his book Education of Girls, he suggested the need to educate all children, irrespective of gender or social status, in order to obtain the best possible social behavior and to cultivate good characters. Moreover, he put forward his arguments for educating girls and he achieved to make their education a social need.

In The Adventures of Telemachus, The Son of Ulysses Fénelon prepared an action plan to help the Duke of Burgundy and throne successor get the moral training that a prince ought to take according to his beliefs. He codified instructions that would affect the personality and behavior of the prince, teaching him the devaluation of human weaknesses in order to lead him to higher spiritual level. Although Fénelon wrote this book for his student, it was welcomed throughout Europe. He promoted humanitarian education as means of prosperity, when education was not institutionalized and children did not have recognized rights yet. The aim of this presentation is to show that Fénelon's ideas on education and moral cultivation of children contribute to their welfare; ideas which are still valid.
\end{abstract}

Keywords: François Fénelon, child well-being, children's education, philosophical thinking, women's education, moral values

\section{INTRODUCTION}

The French Archbishop of Cambrai and pedagogue François de Salignac de la Motte Fénelon (1651-1715) wrote a number of books with philosophical, theological and spiritual perspectives, which are remarkable monuments of the French Church and of the ages of Louis XIV and made virtue to become people-friendly (Hogu, 1920; Hanley, 2020). There are only few writers who have managed to make so many readers to express their admiration for them in an international level such as Fénelon (Orcibal, 1940). He has been a charismatic man, whose personality showed his humbleness and kindness, whilst his spiritual glow never fainted. He made the practice of virtue become his way of living and he never stopped working for the well-being of the society. Due to his pedagogical charisma he became the tutor of the grandson of Louis XIV from 1689 till 1697.

The present study is based on the historical method of analysis (Isari \& Pourkos, 2015, p. 13). Our research on author's works, on his rhetoric in teaching Christian ethics, the subject which he strongly supported, is directly linked to the achievement of child well-being. Fénelon's teaching contributes to build a society of justice, firstly for children and, consequently, for the whole society.

Today, with the term child well-being we refer to the factors that as a whole affect the quality of the life of children. It is an endless effort to fulfill personal and social goals. The study of child well-being focuses on various areas, such as the right to education, children's rights, quality of life, poverty, social exclusion, health care, etc. In order to measure child welfare, we take under consideration both objective, as well as subjective aspects of quality of life. It compensates the positive achievements, together with the difficulties and the shortcomings. At the same time, it takes into account the cultural environment, gender, age 
and various other factors that may affect child well-being (Statham \& Chase, 2010). In the current study we will see that these same aspects are the ones that the Archbishop of Cambrai, François Fénelon, takes under consideration during the writing of his books at the end of the $17^{\text {th }}$ century.

\section{DISCUSSION}

Greek antiquity inspired and influenced the works of 17th-century French classics, such as Corneille, Racine, La Bruyère and Fénelon. The latter had classic education and he was influenced as well by the French educators of the $16^{\text {th }}$ century, Rabelais and Montaigne, who believed that there must be a harmonious configuration of mind and body (Lagarde \& Michard, 2004, p. 45). Among his other literal works, he wrote two pedagogical books; first the Education of Girls, which was written after the request of the Duke and the Duchess of Beauvillier, as they were full of esteem and confidence for Fénelon and they strongly believed that he was the only person who was able to assist them with his advice to bring up their eight daughters with the religious solicitude that they wished to bring to their education, a treatise that he did not intend to publish, and second The Adventures of Telemachus, The Son of Ulysses, which was intended for the education of the Duke of Burgundy and he did not intend to publish it either. Fénelon argued that through education teachers could free their students from bad habits, lead them to higher spiritual level, and help them to their progress. No-one else could support this idea better than Fénelon, as he was the one who managed, with his loving approach, to transform the successor of the throne of France, the Duke of Burgundy, and make him a shining example, because he was stubborn as child and he had bad behavior.

These two books demonstrate the power of literature to exert significant influence on the readers. The Education of Girls is a treatise, which Lamartine denominated it a 'masterpiece of delicacy and reason' (Fénelon, 1891), whereas The Adventures of Telemachus belongs to the literary genre of speculum principum (Kantzios, 2016; Athini, 2015; Schuurman, 2012), it is a pedagogical, philosophical in the type of archaeological novel (Lagarde \& Michard, 1985, p. 425; Puzin, 1987, p. 4; Tabaki, 2008 , p. 64). It reminds us though tales, fables and myths as the writer uses skillfully these different types of writing (Wilbur, 1951), which, of course, have different characteristics as literal genres, but he manages to join morality and storytelling in order to achieve his educational intention and transmit the truth. The books are governed by didactic spirit, they contain essential truths and pure morality; thus, they influenced the philosophical and pedagogical thought, with ultimate aim the achievement of happiness and well-being, which was the goal of François Fénelon, without dry catechisms or mysteries detached from the facts (Fénelon, 1891, p. 52). He calls his readers to have a sympathetic insight into children's heart and behave with care and comfort. These works have been read by thousands of readers across Europe and influenced their thinking (Dru, 2016). In addition, they influenced the thinking of the educators who followed so as to cultivate moral values to students, which are factors that lead to child well-being.

\section{EDUCATION OF GIRLS}

The Education of Girls was written for a small number of people, but it became the principle of Fénelon's high reputation, which led him become the tutor of the grandson of Louis XIV. Although it is a small book, it contains more just and useful ideas, more fine and deep observations, more practical truths and sound morality than any other voluminous work which was ever published since then on the same subject (Fénelon, 1851, p. 82).

Fénelon's contribution to child well-being is significant as he has highlighted the need for all children to be educated, regardless of their gender or social status, and thus girls were given spiritual benefits, which until then, they didn't have (Fénelon, 1891). In his work Education of Girls his frustration is evident, as he realized that the education of the girls was completely neglected (Fénelon, 1911), because the prevailing view was that their education was a luxury of dubious value, which concerned only a few girls, who came either from the noble families or it was addressed to the daughters of wealthy, urban families. People considered that women do not need wisdom, because cultivating their minds made them look ridiculous. The same issue was mocked by Molière in his work Les femmes savantes. Also, Madame de Maintenon claimed, as she addressed to the women of the Court, that it is a matter of modesty for a girl or a woman to pretend ignorance, even when she knows something. The search for knowledge was against women's nature and there were dangers in it (Rapley Elizabeth, 1987, p. 312-313). So, what was considered right for women was to learn to deal with their household and to obey to their husbands.

Fénelon did not hesitate to oppose to those who supported such ideas. He disagreed with the view that women should be prevented from being educated so that they could fulfill the obligations imposed to them by nature or by the society. His theory dares to support that intelligence is not a matter of gender, age or homeland (Fénelon, 1891). For the writer a woman is the soul of the entire household, who provides in it family and spiritual welfare. He argues for the importance of the role of women in modern society, which proves that his thinking is solely inspired by Christian ideals. He reminded to those who were prejudiced, that women are half of the human race; they also come from the blood of Jesus Christ and are destined for eternal life. Such a view is unlike the old way of thinking, which saw women only capable of domestic work and unable to influence their husbands and children morally (Fénelon, 1900, p. 2).

In such a delicate subject, the devotee of Ancient Greek and Latin philosophy presents the Christian principles and his teaching methods (Boulvé, 1970, p. 277). Xenofon's Oeconomicus influenced Fénelon on the writing of this particular work, which in a teaching style like his own, presents a similar subject. The, almost Christian, logic of Oeconomicus attracted Fénelon's interest. While studying the Education of Girls, we realize that many parts have been translated from it. It is not Xenophon who inspired Fénelon to write this work. However, his experience as supervisor at the 'Nouvelles Catholiques', made him aware of the delicate subject of education that suited women, and while there was nothing for him to learn from antiquity that he did not already know 
as a disciple of Apostle Paul on this subject, he turned such a Christian question to the pure and ideal Ancient Greek thought. On the other hand, the education of boys was a recognized need 'the education of boys is regarded as a most important affair with reference to the public welfare' (Fénelon, 1891, p. 11), although Fénelon considered it to be badly organized and so it did not bear fruit. With his views he encouraged the promotion of humanistic and philosophical thought through the cultivation of moral virtue.

The treatise begins from the first days of human life and the author uses a single word to talk about, that of the 'child', wishing to refer to both genders equally, as all the children have got the same weaknesses and the same inclinations. Afterall, Fénelon says that women are the ones 'who ruin or uphold families' and that 'they exert a controlling influence on the good or bad morals of nearly all the world' (Fénelon, 1891, p. 12). He did not want to deprive them of the benefits of cultivating spirituality, which he thought would work well together with their physical gifts. His main concern was the salvation of the girls' souls; for this reason, he wanted them to receive education appropriate to their gender and faith and managed to make their education a social necessity (Rapley, 1987). He indicates the main drawbacks of ordinary education, such as ignorance, sluggishness, idleness, which make people turn towards vain and dangerous habits. The first step is to start the education from infancy. 'That first period of life which is left to the care of foolish, and sometimes vicious women, is the very one in which the deepest impressions are made, and which consequently has a great bearing on the whole of after-life' (Fénelon, 1891, p. 19). He opposed to the practices of the ignorant baby-sitters of that period, who scared children and cultivated various prejudices that followed them throughout their lives, because he, thus, thought that their brains were weakened; women, as well as men, should only rely on religious principles. He said that other practices should not be confused with those derived from the pages of the Bible or from instructions issued by the Church (Bausset, 1817). $\mathrm{He}$ is the first author who ever talked about theological matters for children. In the most pedagogical way he advises parents and teachers to use the simplest language without putting pressure on the children. He wrote rules that should be followed during the education of young girls knowing that they are intended to make family life beautiful with their kindness and tenderness, to educate themselves in the spirit of order and economy, to engrave the first elements in the hearts of their children concerning religious matters and moral education.

Fénelon protests against the reading preferences of young people, such as novels, comedies or chimerical adventures in which profane love is found and he examines the means which can be used to avoid them. In addition, these readings alienate the girls from the real world, which finally make them feel disappointed (Fénelon, 1891, p. 17). He suggests children to listen to the stories of the Creation, about Adam and Eve or the calling of Abraham, which are suitable to turn on children's curiosity, but also show them 'the origin of religion' and 'lay a foundation for it in their minds' (Fénelon, 1891, p. 51). But he wanted to make sure that children must be protected and 'warned against certain abuses which are so common that one is tempted to regard them as parts of the present discipline of the Church, if one is not well informed', as superstition overwhelmed women and sometimes they confused it with faith (Fénelon, 1891, p. 70). Furthermore, Fénelon encourages the use of good pictures during a narration, because 'the power of color added to the grandeur of life-size figures will strike the imagination more forcibly' (Fénelon, 1891, p. 56); an opinion which Diderot will emphasize and enlarge in the 18th century in his Encyclopedia, where he popularized knowledge and presented it with image.

Fénelon cares for children's health. He points out that during the first years of childhood, parents ought to make sure that children will establish good health. That can be achieved by offering to them well-chosen food, which will be always offered at about the same hour, but most important it must be provided as often as the child's needs require it. Children's food must be healthful and should not be highly seasoned; he advises to avoid eating between meals, as this causes problems to digestion, but also there should be a variety of dishes (Fénelon, 1891, p. 21). Nevertheless, he is not in favor of fancy dishes to rouse appetite, because they lead to intemperance. Whereas temperance produces health of body and soul and so people enjoy calm and gentle happiness. At the same time, the writer rejects the consumption of wine as it injures health (Fénelon, 1891, p. 40-41). Furthermore, he comments about the sleeping habits and the duration of sleep, which is necessary for perfect health (Fénelon, 1891, p. 16).

The curriculum that he proposes includes lessons of Latin, history, biography, travels, poetry, music and art, but he goes even further as he wants girls to have knowledge of the principles and phraseology of common law, the operations of trade, the procedures of manufactures, as well as domestic economy (Fénelon, 1891). Arithmetic will help them to keep accounts which produces good order in households. But they must be able to understand 'the difference between a will and a deed of gift; the nature of a contract etc'. Moreover, the writer insists that the girls must realize that the law is full of obscurities and doubtful rules, that jurisprudence varies and when all depends on judges everything becomes uncertain, even if it may seem clear to them (Fénelon, 1891, p. 105-106). His aim was to create the conditions that would lead to the best possible social behavior, 'she opens her mouth with wisdom, and a law of kindness is on her tongue' (Fénelon, 1891, p. 119), he wanted to create children with diamond character and, when he presented his arguments for the education of girls' in this treatise, he succeeded in making their education a social need (Rapley, 1987). As Fénelon says in his letter of 23 November 1714 to the Duke of Chaulnes the student ought to learn to watch over himself against himself; students will receive knowledge from the tutors as divine light (Fourgnaud, 2012, p. 435).

The useful advice that he gives through this project, which is aimed at both teachers and parents, is intended to influence his social environment in order to create better conditions for children's living and development. He introduced a humanitarian educational system, because he believed that teachers should recognize each child as a distinct personality; they should be interested in their development as well as their interests. In this way, children could benefit greatly from the guidance of the teacher. Fénelon's suggestions for ensuring child well-being includes strict pieces of advice for parents and teachers. Firstly, the educator's attention should be focused on the educational process (Gill, 2010). Parents must choose wisely the educators of their children, 'try to select persons of talent to take charge of children' (Fénelon, 1891, p. 56). Positive feelings are created in children when parents and teachers approach them with kindness and persuasion, while rigor does not provide any benefit (Fénelon, 1891, p. 46). Educators should tolerate the shortcomings of their students and wait for the appropriate opportunity to intervene constructively, when the child is ready to receive the appropriate instruction (Castex \& Durer, 1945). There is no need for teachers to load children with hard work. Their curiosity will awake gradually. Teachers need to show their students the benefits of 
completing their work, so that they can feel happy and satisfied afterwards (Fénelon, 1891, p. 56). Parents and teachers should avoid punishment. Instead, students should learn to understand their mistakes. This will result in a sense of security, but also in the development of their judgement (Fénelon, 1891, p. 36). Moreover, we find instructions for mothers on how to lead their children, how to treat their servants, but also how to regulate the house and monitor the household. There are instructions also for the women and housekeepers who assist mothers to the education of their children. This guidance gets absolutely helpful by the clarified details and examples, which justify the truthfulness of his words.

He encourages the dialogue with children on issues that children have some knowledge about, but at the same time parents or teachers provide them with more information in order to learn more and fill in the gaps (Fénelon, 1891, p. 61). Teachers should be close to children and should not be arrogant. They should use friendly language to explain and create a supportive environment so that the thought process can be structured. They should, also, follow the example of the Ancient Greeks and teach through music and poetry. He believes that when these arts are used successfully, the soul gains courage and cultivates love in virtue (Fénelon, 1891, p. 109). But also, in the ecclesiastical life, music has a significant meaning, 'Hymns were the first records that preserved more distinctly, before the scriptures, the tradition of divine things among men' (Fénelon, 1891, p. 110). Children need to be rewarded by parents or teachers, because if they are not, they might get discouraged, but the reward should not be with ornaments or dainties, as these are things that should be despised; Fénelon suggests the rewards to be innocent games, walks with fruitful conversations or little gifts like pictures, medals or books (Fénelon, 1891, p. 45). In general, the writer wants children to be instructed in such a way that they will find virtue lovable and he insists on emulation and encouragement.

In addition, he wishes to preserve girls from their usual faults, which they actually get through their education; softness or excessive shyness makes them incapable of firm and settled conduct, they should avoid participating in useless speeches and rumors, or the artificial detours in order to reach their goals. Vanity and desire to please are tendencies from which the author wants to prevent girls and he wants them to understand that such graces are useless, dangerous and they are not supported by merit and virtue. They should avoid adjustments; they should not be eager to follow fashions or do other little things which make them contemptible in front of wise men.

As an educator, Fénelon understands the importance of each of the areas for developing students' skills, e.g. linguistic, cognitive, social and emotional, all of which are influenced during the lessons and play an important role together in the development of children and their well-being. He does not forget to underline that most of everything is important the correct principles and the edifying examples that parents must give to their children (Fénelon, 1891, p. 118). As actions are more impressive than words, children need to see the person who teaches them act accordingly and not assume virtue as an impracticable idea (Fénelon, 1891, p. 67). Actually, he attempted to write what a woman should learn in order to be source of happiness and support for her family. He wanted to enable them to bring peace in their home during the difficult days that often afflict human life, to provide society with courtesy, grace and decency, qualities which are necessary to soften the incompatible and imposing character of men. He wanted women to be able to cope with the unjust habit that deprived them from education and enable them to pursue the acquisition of knowledge, which is necessary and useful to them (Bausset, 1817).

\section{THE ADVENTURES OF TELEMACHUS, THE SON OF ULYSSES}

The Adventures of Telemachus is the book to which Fénelon owes much of his later fame. By reading its pages, we realize that Fénelon visualized his views to influence the political life of France. Fénelon conceals his views on the politic situation of the country in the utopic environment of this epic poem and hence he avoids to express apparent criticism (Ahn, Schmitt-Maass \& Stockhorst, 2013, p. 5). He wanted to make his book a tool of spiritual awakening and he presented it as a follow-up to Homer's Odyssey; he wanted to instruct the Duke of Burgundy, whilst he was getting entertained. It is a dramatic fiction, and by no means a treatise, which features the program for the educational process of the young prince, who is destined to rule, imposing that people are not made for the king, but the king for the people (Fénelon, 1891) and it contributes to the cultivation of humanitarian awareness (Ioannou \& Malafantis, 2019). So, the ultimate goal is the prosperity of both the prince himself and his people and the writer intends to awake the prince's conscience.

In this book we discover Fénelon's personality, his way of thinking, his pedagogical perceptions and his doctrinal theory (Puzin \& Violette, 1988, p. 279-280). He coded instructions that would influence the prince's personality and behavior (Castex \& Surer, 1946, p. 236), teaching him to depreciate human desires and weaknesses to lead him to higher spiritual level (Athini, 2015). His work does not make any reference to the Bible or to the Catholic preaching. Far from being a Catholic Archbishop, Fénelon appears as a mentor, by taking the form of goddess Athena; he becomes a wise and lucid guide who helps Telemachus. In every single step that Telemachus makes, he is followed by a divinity, who assists him and makes his triumphs more glorious and his dangers more interesting. The goal of his mentor is to help him become autonomous by placing him in front of dilemmas.

The author consciously chose to place his work chronologically in Ancient Greece, because it is the ideal time for him to present ethically exemplary characters (Bottigheimer, 2003, p. 172). The journey in time and space provokes philosophical reflection to the successor of the throne. Iliad, Odyssey and Aeneid are beautiful poems, but their heroes have also some defects. The subject of this book is of universal concern, as Telemachus, who is its hero, comes from the nature of man; there is nothing more touching than filial tenderness, nothing more worthy of all wishes, than a wise and happy kingdom. Achilles in Iliad is almost always nervous and vengeful; Ulysses in Odyssey is often false and misleading, whereas Aeneas is weak and superstitious; thus, Telemachus feels comfortable by himself, he is courageous without ferocity, he negotiates without artifice, he is tender without weakness, he is firm without obstinacy, he is wise without ostentation, he is passionate without excess. 
The ethics of Telemachus is better presented, it is more extensive, touching and universally useful; every nation can take lessons that suits them. The writer's concern is to form a warrior prince, equitable, virtuous, legislator, but also docile, hardworking, valiant and faithful, because he wants to create happy people and, through those virtues, guarantee their well-being. The book teaches the art of governing different nations; it presents the means that a good king should use to preserve peace with the neighbors, how to strengthen a kingdom outside without use of violence, but also to ensure activity in the kingdom by wellconcerted actions, to enrich it by trade and agriculture, to exclude luxury, to prevent corruption and ensure independence by wise laws. It teaches to respect religion, show esteem to the beautiful nature, show love and respect to the parents and to the country; furthermore, the reader learns the art to be a good citizen, how to become a good friend, but even if that is the will of fate, to accept it and be unhappy or slave (Gosselin, 1851, p. 98).

In addition, in this work, with remarkable clarity and elegance, Fénelon promoted his ideology of political wisdom. He introduces the philosophy of life according to the Epicurean conception of happiness, as he looks for the necessary needs and fights against vain pleasures (Fourgnaud, 2012, p. 441). The writer, in the form of the goddess Athena (Shennan, 1991, p. 691) reveals to his pupil the values of life, truths and virtues; so, the prince gets the impression that he can identify himself to the hero of the story and learns to find in himself the conditions of happiness, whilst his mentor urges him to become autonomous and decisive as he ought to choose between difficult alternatives. The story constitutes the means for the procedure of the enlightenment of minds and consciences, which the writer wishes to achieve.

Fénelon believed that the education that he provided to the prince, as his personal tutor, would ensure prosperity for him and his people. He explains the way that tutors and parents should bring into the minds of children the first principles of religion. For his student, not only did he want to ensure the Christian formation of the future king, but he wanted to provide him with all the necessary means to become a good, virtuous prince. Portraits of kings, either good or bad, are presented so that the student will emulate their example or he will renounce them.

His writing skills allow him to present his ideas, which include the most severe justice. Based on the Christian religion, he reminds to his pupil that people have got to be united and that they ought to establish a correspondence of mutual aid. They should think with their hearts in favor of humanity, but also to take care of the unfortunate in life, without minding the nation from which they come. The author draws the attention to the way that the kings choose their counselors; the kings must be able to estimate the piece of advice that they receive so as not be manipulated. The leaders have got to be perceptive and able to predict to a long period of time the results of their policy, but also, they must be wise when they have to act like judges (Hanley, 2020).

The protection of the Duke from the members of the Royal Court, who were willing to satisfy his every single wish and thereby spoil him, was Fénelon's responsibility (Fénelon, 1847, p. 35); he argues that people who live without deprivation do not deserve to be happy, because they become demanding and arrogant due to the abundance which surrounds them. In fact, this condemnation of wealth is addressed to the King Louis XIV and to the nobles of Versailles, who exploited the poor. In addition, the author abhorred any satisfaction that comes from addictive pleasures and he considered the consumption of alcohol to be catastrophic, as it endangered virtue (Fénelon, 1847, p. 56). The prince should be taught patience, he should be wise and afterwards he should learn to behave bravely. It is the prince's duty to love his people, to provide them with happiness and to teach them to associate the idea of prosperity with him (Fénelon, 1847, p. 19-20). Fénelon wants people to consider their king as the person who protects them, as a father, in the way that Xenophon presents the king in his book Education of Cyrus (Ahn, 2008, 2012). For the author, wisdom and knowledge are indispensable to a king who works for the well-being of his people.

'... it was his custom to give audience, at a certain hour every day, to all who had any complaints to make, or intelligence to communicate; nor was any man either despised or rejected by Sesostris; he considered himself as possessing the regal authority, only that he might be the instrument of good to his people, whom he regarded with the affection of a father...' (Fénelon, 1847, p. 22).

Fénelon expresses direct criticism to the King by arguing that wars increase the wounds of nature and cause new deaths, which result in the destruction of the human race, as well as children's poverty and to the desolation of the earth. He criticizes the King's ambition of spreading his kingdom, because it causes torment and misery to people (Schuurman, 2012). But he is fond of those princes, who speak of war only when it is necessary to defend their home country, than those who think only of military action. He accuses the latter of destroying their people and shed blood just to add new titles to their names. During war laws are violated with impunity, agriculture is neglected and there is no progress in the field of the sciences. People, no matter if they belong to the winners or losers of a war, suffer equally among the ruins. Occupying a neighboring country by force has as a consequence to make neither of the population happy (Fénelon, 1847, p. 88-89). The disasters of war cause greater misery to the less favored, and the writer invites the educated people to re-evaluate their ethics and values (Fénelon, 1847, p. 149). He acknowledges the virtue of the character that some kings have and can lead effectively either on war or peace and their cautiousness gives them the ability to choose the best action based on the circumstances, but also the moderation to work for the public interest and not to fulfil their personal desires (Hont, 2006).

Fénelon values health and freedom, but also austerity and the power of body and mind. Furthermore, he considers the ability to govern in peace to be followed by moral strength. He claims that happiness and progress are found in simplicity and in the joy that work provides (Hont, 2006). 'As to the pacific prince, it must, indeed, be confessed, that he is not qualified for conquest; or, in other words, he is not born to harass his people by perpetual hostilities, in a restless attempt to subjugate others, over whom he can have no equitable right' (Fénelon, 1847, p. 89). Such governance will create brave citizens, who will not be afraid to fight for their country in order to protect it, but also, these citizens will protect a prince who reigns only on the basis of good thinking and reason (Fénelon, 1847, p. 90-91). At the same time, Fénelon considers knowledge as a kind of fun and the cultivation of mind to be nothing less than 'supreme delight' (Fénelon, 1847, p. 25-26). He believes that bad habits and pleasures during youth 'precipitate old age'. He argues that life should be wisely 'divided in due proportions between labour and rest' (Fénelon, 1847, p. 163). 


\section{RESULTS}

The political ideal is getting linked to the moral ideal by Fénelon, who suggests that the achievement of a peaceful and tolerant society is based on virtue. Apparently, the writer seeks to cultivate virtue to the prince and to all the children to shield them from any danger in order to lay the foundations of well-being. Fénelon cares for children's welfare and, on the one hand, he believes that the positive state in which they should live can be achieved by education. He does not simply wish for the absence of negative situations. According to Fénelon, children experience well-being when they feel the comfort that their family can offer them and the family is connected and united. The relationships within and beyond the family ought to be encouraged; family members must support each other and have the opportunity to work and praise God. Families get their needs met with the auspices of God and the security and serenity that a good king provides. We understand that the writer would consider a community being successful on the subject of child well-being when all children are being treated with respect, they are loved, get their rights, as human beings, fulfilled and the conditions are in place to allow all children to achieve meaningful lives.

Fénelon does not correlate education with children's gender. In his book Education of Girls, even though the title leads to the female kids, he focuses on his subjective point and discusses about improving children's, in general, learning skills and solving their behavioral problems, which are part of the way to establish well-being. By working primarily on the emotional attitude of the child, Fénelon tends to show them love and care, with ultimate goal to help them feel safe. The author knows that children have the possibility to thrive, but it is up to the adults to ensure that their abilities will grow. He gives examples that parents and teachers can follow to help children with their social skills, their learning ability, but also their emotional intelligence in order to ensure proper support for them. Taking advantage of children's curiosity can become the best opportunity to explain different things to them; no matter if it concerns theological truths or any other subject. Children should be taught to have good judgment; even if they lack sometimes to make the right choices, they must be taught to realize their mistake, with love and not through punishment. Children's minds are flexible and can adapt things easily according to the example that they see, but also it must be clear to them where they should focus. Furthermore, the cultivation of empathy can be achieved when children are requested to collaborate, as they get to know each other and feel like a team.

Today, expectations, obligations, practices have changed significantly concerning children's well-being, which is rather constructed by the influence of demographic and social conditions, political systems, professional opinions and culture. The different perceptions on the subject unavoidably become part of conflicting cultures or explanations, whilst Fénelon's contention, which includes historical and cultural features, supports education as the root of children's well-being. His pedagogical approach is the first step to consider children as human beings with their particular needs and capabilities, which must be met in order to set the standards of well-being in general. By introducing children's philosophy and pedagogical principles through his writings, the author establishes ideas to enhance critical, creative and caring thinking; these, as pedagogical tools, can be flourished through education and will help children to become able to participate fully in the society.

Likewise, in The Adventures of Telemachus, The Son of Ulysses children's well-being seems to be able to be achieved by the king's policy which should guarantee peace, instead of introducing a regime of war, that would put the security of people in absolute danger, which would generate, as well, an abhorrent financial system, resulting in public dept, corruption and hypocrisy from the members of the Court. Children's well-being is being strained when they live in state of war, because it causes not only poverty, insecurity and loss, but it is true that children are exposed to highly dangerous and traumatizing situations; the impact of armed conflicts provokes family displacement, rise of sicknesses, as well as proliferation of attacks that victimize children. The experiences of children who have lived under the state of war differ, as others have become eye-witnesses of the death or the murder of members of their family or others; in such cases children present a range of emotional and behavioral problems and they face numerous challenges upon their recovery.

The cultivation of virtue through education, expressed in rules, as Fénelon tried to do, can lead to the denial of individual interests or personal needs, and up to the point which refers to children, it may lead to become possible to overcome the difficulties which arise and make their well-being realizable. For the writer, it is not just the matter of learning philosophy, but to live according to a philosophical way, in order to have mental quality of life. Fénelon knows that the development of intelligence can become a dangerous weapon in the hands of a person without conscience. For every single person conscience is the rule of feelings and thoughts, it is shelter against passions and strength against the weakness of nature; therefore, it is even more useful for a king who has in his hands the future and the well-being of his people (Fleuriot, 1865, p. 715). Thus, the myth develops gradually and its effects employ political, moral and philosophical values. The way of living in Fénelon's ideal kingdom poses questions and the reader studies the society and its perceptions, in order to better understand them and, as a consequence, participate in the advent of a new, honest and more enlightened society.

These two literary works of Fénelon accentuate the process of humanizing morality, which is a basic step for the achievement of well-being. Their didactic value is found in the effort that each one can fight against each own faults, take on a humble way of life, get educated and make it possible to completely change their life.

\section{CONCLUSION}

With these two literary works Fénelon promoted humanitarian education as means of well-being, when education was still not institutionalized and children had no recognized rights yet. He supports a conservative and simple lifestyle for the achievement of children's subjective and objective well-being. It is clear that the author is striving to cultivate virtue to both the prince and to every child, in order to shield them against any danger and build the foundations of well-being. The reception of Fénelon's views 
on education and on the moral upbringing of children by the philosophers and educators have contributed to the achievement of child well-being, and his ideas continue to be still valid and they get replicated by today's educators too.

\section{REFERENCES}

Ahn, D. (2008). The politics of royal education: Xenophon's Education of Cyrus in early eighteenth-century Europe. Leadership Quarterly, 19, 439-452. https://doi.org/10.1016/j.leaqua.2008.05.008

Ahn, D. (2011). From Greece to Babylon: The political thought of Andrew Michael Ramsay (1686-1743), History of European Ideas, 37(4), 421-437. https://doi.org/10.1016/j.histeuroideas.2010.12.005

Ahn, D., Schmitt-Maass, C. \& Stockhorst, S. (2013). From Idonemeus to Protesilaus: Fénelon in early Hanoverian Britain, Fénelon in the Enlightenment: Traditions, Adaptations and Variations, Rodopi, Amsterdam, 5. https://doi.org/10.1163/9789401210645_007

Athini, S. (2015). The presence of François de Salignac de la Motte Fénelon in the modern Greek education (18th - 19th century). Logos kai xronos sti Neoelliniki Grammateia (18th - 19th century), Conference proceedings in honour of Alexis Politis, Rethymno, 12-14 April 2013, Heraklion, 106-111.

Bausset De, L.-F. (1817). Histoire de Fénelon, Archeveque de Cambrai. Tome premier. Versailles, De l'imprimerie de J.A. Lebel.

Bottigheimer, R. (2003). Fairy Tales, Telemachus and Young Misses Magazine: Moderns, Ancients, Gender and Eighteenth-Century Children's Book Publishing. Children's Literature Association Quarterly, 28(3), 172. https://doi.org/10.1353/chq.0.1526

Boulvé, L. (1970). De l'Hellénisme chez Fénelon. Genève, Slatkine Reprints.

Castex, P. G., \& Durer, P. (1946). Manuel des études Littéraires Francaises Moyen Age, Classiques Hachette, Paris, $1946,235$.

Dru, A. (2016). Fénelon in History. The Downside Review, 86(282), 1-12. https://doi.org/10.1177/001258066808628201

Fénelon, F. (1847). The adventures of Telemachus, the son of Ulysses. Manchester, Thomas Johnson, Oldham Str.

Fénelon, F. (1848-1852). Oeuvres complètes de Fénelon,......, Tome Premier, Paris, J. Leroux \& Jouby, Libraires, Gaume \& Cie Libraires. Retrieved from http://catalogue.bnf.fr/ark:/12148/cb304261335

Fénelon, F. (1851). Auteur du texte. Oeuvres complètes: précédées de son histoire littéraire par M. Gosselin, Tome 1 / Fénelon. 1851-1852. Retrieved from https://gallica.bnf.fr/ark:/12148/bpt6k7726h/f1.image

Fénelon, F. (1891). The Education of girls. Boston: Ginn \& company.

Fénelon, F. (1911). Lectures littéraires. Pages choisies des grands écrivains: Fénelon / avec une introduction par M. Moïse Cagnac. A. Colin, Paris.

Fénelon, F., (1900). Fragments from Fénelon concerning education; New York, Bonnell, Silver \& company. Retrieved from https://lccn.loc.gov/15004330

Fleuriot, Z. (1865). La Semaine des familles: revue universelle illustrée, Paris. Retrieved from http://catalogue.bnf.fr/ark:/12148/cb344730672

Fourgnaud, M. (2012). Du conte didactique au conte philosophique, de Fénelon à Saint-Hyacinthe. Dix-huitième siècle, 44(1), 461483. https://doi.org/10.3917/dhs.044.0461

Gill, N. (2010). Educational Philosophy in the French Enlightenment: From Nature to Second Nature, Ashgate Publishing, Farnham, 105.

Hanley, R. P. (2020). Fénelon. Moral and Political Writings. NY: Oxford University Press. https://doi.org/10.1093/oso/9780190079581.001.0001

Hogu, L. (1920). Le mythe de Fénelon. Revue d'histoire de l'Église de France, 6(30), 5-14. https://doi.org/10.3406/rhef.1920.2136

Hont, I. (2005). Jealousy of Trade: International Competition and the Nation-State in Historical Perspective. Cambridge, Massachusetts: The Belknap Press of Harvard University Press.

Hont, I. (2006). The Luxury Debate in the Early Enlightenment, in Mark Goldie \& Robert Wokler (eds.) The Cambridge History of Eighteenth-Century Political Thought, Cambridge University Press. https://doi.org/10.1017/CHOL9780521374224.015

Ioannou, A. X., \& Malafantis, K. D. (2019). The Contribution of the Literary Works of François Fénelon 'The Adventures of Telemachus, Son of Ulysses' and of Voltaire 'Candide', to the Cultivation of Humanitarian Awareness. Pedagogical Research, 4(4), em0042. https://doi.org/10.29333/pr/5879

Isari, F., \& Pourkos, M. (2015). Qualitative Research Methodology, Applications in Psychology and Education, Greek Academic Electronic Texts and Assistives, 13.

Kantzios, I. (2016). Fénelon's Subversive Uses of Aeneid 6. The Comparatist, 40, 190-204. https://doi.org/10.1353/com.2016.0011

Lagarde, A., \& Michard, L. (2004). XVIIIe SIECLE. Paris: Bordas, pp. 114-115.

Orcibal, J. Fénelon et la Cour romaine (1700-1715). In: Mélanges d'archéologie et d' histoire, tome 57, 1940. pp. 235-348. https://doi.org/10.3406/mefr.1940.7318

Puzin, C. (1987). Littérature, Textes et Documents XVIIe siècle. Paris: Nathan, 463.

Puzin, C., \& Violette P. (1988). Littérature, Textes et Documents XVIle siècle. Paris: Nathan, 279-280. 
Rapley, E. (1987). Fénelon Revisited: A Review of Girls'. Education in Seventeenth Century France, Histoire sociale - Social History, XX(40), 299-318.

Schuurman, P. (2012). Fénelon on Luxury, War and Trade in the Telemachus. History of European Ideas, 38(2), 181-183. https://doi.org/10.1080/01916599.2011.652473

Shennan, J. H. (1991). The rise of patriotism in 18th-Century Europe. History of European Ideas, $13(6), 691$. https://doi.org/10.1016/0191-6599(91)90136-M

Statham, J., \& Chase, E. (2010). Childhood well-being research, Centre Briefing Paper1, August.

Tabaki, A. (2008). Zitimata sygritikis grammatologias kai istorias ton ideon, Ennea meletes, Athens: Ergo, 64.

Wilbur, S. H. (1951). Oratory and poetry in Fénelon's literary theory, Quarterly Journal of Speech, 37(1), 1-10. https://doi.org/10.1080/00335635109381612 